\title{
Korean Peninsula Nuclear Challenges: The Imperative of Regional Cooperative Security Solutions ${ }^{1}$
}

\author{
By Wade L. Huntley (Canada)
}

\section{Introduction}

1 Bush Administration prides itself on responding "realistically" to serious intemational threats. But its policies toward North Korea have been more responsive to some officials' self-generated aspirations than to actual circumstances prevailing on the Korean Peninsula and in the East Asian region. The predilections behind the Bush Administration's North Korea policy reflect the deeper ideationallyinspired world view driving much of the administration's international behavior. This orientation persists despite the more practical tone of the Bush Administration's approach to North Korea in its second term.

The administration's continuing commitment to ideationally informed outlooks has impeded effective response to North Korea's nuclear ambitions. Partly for this reason, North Korea's nuclear capabilities have advanced in recent years, culminating in the October 2006 muclear test. In this context, the February 2007 agreement emerging from the Six-Party Talks was a welcome tum back in the direction of a nuclear-free Korean Peninsula. Now more than ever, however, achieving that goal depends on parallel progress toward establishment of a durable regional security regime in Northeast Asia that includes conflict resolution mechanisms to replace reliance on nuclear threats for national searity.

\footnotetext{
${ }^{1}$ Paper presented at: Northeast Asia Regional Steering Group Meeting Global Partnership for the Prevention of Armed Conflict (GPPAC-NEA) Ulaanbaatar, Mongolia - May 24-25, 2007
} 


\section{The US Disposition}

Throughout its first term, the Bush Administration made little effort to shape its North Korea policy on the basis of extant conditions. Instead, it based policy fundamentally on assumptions about the Pyongyang regime's character. As those assumptions proved specious its North Korea policy floundered, increasing strains with other regional governments, including ally South Korea. ${ }^{2}$ The inability of the administration to adapt its ineffective policy to changing circumstances stermed from the roots of that policy in the administration's powerful and inflexible predispositions concerning the extent of US power and the rectitude of the administration's overarching global vision.

As Pentagon strategists absorbed the implications of the end of the Cold War, US military planning throughout the 1990s increasingly expressed the aim of military "dominance," and foresaw a continuing role for US nuclear weapons in this posture. But the Bush Administration's policies superseded this ambition, mapping out intentions for new strategies aspiring to put us gldbal political "primacy" to the service of transforming world politics in the American image. ${ }^{3}$

In its second term, the Bush Administration has reaffirmed the core tenets of this strategy. President Bush's second inaugural address reiterated that "it is the policy of the United States to seek and support the growth of democratic movements and institutions in every nation and culture, with the ultimate goal of ending tyranny in our world. ${ }^{4}$ In early 2006, the administration's long delayed update of the National Security Strategy emphasized this core intention even more forcefully than its 2002 predecessor, identifying as its two foundational pillars the

${ }^{2}$ See "Korea Backgrounder: How The South Views Its Brother From Another Planet," Intemational Crisis Group Asia Report No89, Seoul/Brussels, December 14, 2004, pp.2123

${ }^{3}$ The 2001 Quadrennial Defense Review (QDR) and the 2002 Nuclear Posture Review (NPR) map out a fundamental shift from a "threat-based" to a "capabilities-based" approach intended to "extend America's asymetric advantages well into the future." The 2002 National Security Strategy (NSS) articulates these ambitions, determining to "create a balance of power that favors human freedom" and "extend the peace by encouraging free and open societies on every continent." The QDR is available at http:/ /www.defenselink.mil/pubs/qdr2001.pdf>. The NPR was first publicly sumarized at a Department of Defense briefing on Jamuary 9, 2002; the classified review was subsequently obtained by news media, and substantial excerpts are available at http:// www.globalsecurity.org/wmd/library/policy/dod/npr.htm >. The $2002 \mathrm{NSS}$ is available at //www.whitehouse.gov/nsc/nss/2002/. All links accessed December 14, 2006.

${ }^{4}$ President George W. Bush, Inaugural Address, January 20, 2005 :// www.whitehouse.gov/news/releases/2005/01/print/20050120-1.html 
aims of "promoting freedom, justice and human dignity" and "leading a growing community of democracies." ${ }^{5}$

This vision of virtuous US global leadership based on dominant military power harkens to a nineteenth century idealist intemationalism underpinned by the security of broad oceans, and so represents the reascendance of idealism over realism in shaping us grand strategy. But it is a particular form of idealism: the active promotion of overseas democratization, by force if necessary, pushes aside aspirations to constitute a society among states, aiming instead to challenge the prerogative of state sovereignty itself. President Bush's recent repudiation of the Yalta agreements forged at the end of World War II evinces this viewpoint. ${ }^{6}$ The Bush Administration's emergent grand strategy thus represents a triumph for emancipatory militant idealism over liberal intemational idealism?.

This emancipatory militant idealism drives the Bush Administration's approach to nuclear proliferation. The administration's policy documents focus less on nonproliferation than on preemptive counter-proliferation to el iminate specific adversaries' WMD capabilities before they are used - or even fully realized. ${ }^{8}$ US counter-proliferation planning includes possible nuclear weapons use, driving calls in the Nuclear Posture Review for development of nuclear capabilities applicable to such roles.

In this view, there is no contradiction in threatening nuclear attack to thwart nuclear proliferation, because nuclear weapons themselves are not really the problem; the presence of nuclear weapons in the hands

${ }^{5}$ The 2006 National Security Strategy is available at <http://www. whitehouse.gov/ nsc/nss/2006/>, accessed December 14, 2006

${ }^{6}$ Speech by President George W. Bush, The Small Guild Hall, Riga, Latvia, May 7, 2005<http: //estonia.usembassy.gov/freedom.php>.

${ }^{7}$ For a more detailed exposition of this interpretation, see Wade L. Huntley, "Threats All The Way Down: U.S. Nuclear Initiatives in a Unipolar World," Review of Intemational Studies $32: 1$ (January 2006), pp 49-67. For a similar distinction between contending strains of US foreign policy idealism, see Jonathan Monten, "The Roots of the Bush Doctrine: Power, Nationalism, and Democracy Promotion in U.S. Strategy," Intemational Security 29:4 (Spring 2005), pp. 112-156

${ }^{8}$ The Bush Administration's National Strategy to Combat Weapons of Mass Destruction (White House December 2002) offers only a single paragraph on the role of "active nomproliferation diplamacy," which simply reiterates the need for "a full range of operational capabilities" if the efforts fail (p.4). See also National Strategy for Combating Terrorism (White House, February 2003). 
of bad states is the problem. Hence, increased US reliance on nuclear threats is actually part of the nomproliferation solution, and greater US commitment to nuclear disarmament is irrelevant. This view is the intemational equivalent of US conservatives' credo opposing gun control: guns don't kill people; bad people with guns kill people.

Appreciating these ideational roots of the Bush Administration's policies elucidates its approach to North Korea. The Bush Administration's distaste for engaging North Korea diplomatically expresses a deeper conviction that the current Pyongyang regime is an international miscreant that does not deserve the prerogatives of sovereignty. This conviction drives the administration's tenacious courting of "regime change" as the ultimate solution to the nuclear crisis. Persistent anti-diplomatic rhetoric emphasizing that North Korea camnot be "rewarded for bad behavior" evinces the posture of a parent or a sheriff - one does not negotiate with children or outlaws.

This outlook also shapes the administration's viewpoints on the implications of North Korea's nuclear ambitions. North Korea's nuclear weapons development poses several challenges to the global nomproliferation regime: the potential East Asian regional repercussions, the corrosive impact on the NPT itself, and the possible proliferation of nuclear materials and expertise. The Bush Administration's responses to these concerns evince its preoccupation with particular nuclear aspirants rather than proliferation as a systemic problem per se, expressing the ideational predispositions shaping its outlook on global nuclear challenges.

- A steadily (if slowly) growing arsenal of muclear weapons in North Korea will aggravate tensions and uncertainties in East Asia. Some worry North Korea's actions could trigger a nuclear proliferation "domino effect" in East Asia, and particularly might spur Japan to obtain nuclear weapons of its own. In fact, Japan is probably less prone to soon pursue nuclear weapons than some fear. ${ }^{9}$ But the Bush Administration's relative quiescence toward the prospect that North Korea's activities might spur Asian proliferation does not rely on Japanese forbearance. Indeed, at one point, as the

${ }^{9}$ In 1995 the Japanese Defense Agency compiled a 31-page secret report reaffirming previous government studies' conclusions that developing nuclear weapons would damage Japan's national and regional security interests. The existence of the report was disclosed by the Asahi Shimbun on 20 February 2003 ://www.globalsecurity.org/wmd/world/ japan/nuke.htm, accessed Dec. 14, 2006. Cf. Matake Kamiya, "Nuclear Japan: Oxymoron or Coming Soon?" Washington Quarterly 26, no. 1 (Winter 2003) : 63-75. 
Agreed Framework was collapsing, the administration seemed to signal that it might view a nuclear Japan more benignly than previous US governments. ${ }^{10}$

- North Korea is the first state ever to withdraw from the NPT. There are no good options to mitigate the impact of its withdrawal on the NPT itself and on the wider nomproliferation regime: either continued North Korean non-accession or re-accession under a unique deal would set precedents eroding current NPT compliance norms. Yet the Bush Administration rarely expresses worries over these kinds of impacts. On its face, the silence is striking; but given the administration's expressed lack of faith in both nonproliferation and intemational treaties, its dispassion over diminution of the NPT regime is hardly surprising.

- North Korea's reinvigorated nuclear program gives it the potential to export fissile materials, nuclear weapons development technologies and expertise, or even completed operational weapons. This is the consequence of a nuclear North Korea that the Bush administration takes most seriously; preventing it has apparently become the administration's genuine "red line." Bush Administration's principal response - the Proliferation Security Initiative (PSI) - has gained greater legitimacy as it has garnered more national adherents and the endorsements of the G8 Global Partnership and the UN Secretary General. ${ }^{12}$ But, by design, the PSI remains disassociated with multilateral

\footnotetext{
${ }^{10}$ Vice President Richard Cheney as stated that, in response to North Korea's development of nuclear weapons and missiles, "Japan may be forced to consider whether or not they want to readdress the nuclear issues." Asahi Shimbun, 17 March 2003, // www.globalsecurity.org/wmd/world/japan/nuke.htm, accessed December 14, 2006. The comment came in the context of considerable US discussion spurred by Charles Krauthammer, "The Japan Card," Washington Post, January 3, 2003

11 "N.K. Nuke Test No Red Line, Former U.S. Negotiator Says," Chosun Ilbo, April 28,2005; David E. Sanger, "Bush Shifts Focus to Nuclear Sales by North Korea," New York Times, May 5, 2003

${ }^{12}$ G8 Action Plan on Nonproliferation, Sea Island Summit 2004 ://www.g8usa.gov/ home.htm; A More Secure World: Our Shared Responsibility, Report of the UN Secretary General's High-level Panel on Threats, Challenges and Change, United Nations, 2004, p.45.
} 
nomproliferation treaty regimes that could expand its acceptance and effectiveness. ${ }^{13}$

These responses to the several consequences of North Korea's nuclear weapons development stem from the Bush Administration's lack of faith in multilateral nomproliferation efforts generally, which itself stems from the emancipatory militancy at the core of its "grand strategy" for the US global posture. This viewpoint drives the administration's apparent reticence to abide Pyongyang as a sovereign interlocutor, and its implicit (though often denied) conclusion that ultimately a satisfactory settlement of the nuclear confrontation will require regime change in North Korea. Given such a conclusion, the administration's relative quietude over the deleterious consequences of a nuclear North Korea may simply express a de facto decision to minimally tolerate extant circumstances until regime change (natural or facilitated) solves the problem. This strategy to "contain and strain" North Korea appears to be the last best hope of the Bush Administration's hard-liners.

\section{Negotiations \& Consequences}

Upon coming to power in early 2001, more hard-line administration officials judged that the Clinton Administration's engagement of North Korea had been mere "appeasement." These individuals were unconcerned over the risks of a more confrontational approach to the Agreed Framework structure that had defined the relationship of the two countries since 1994. Indeed, some openly advocated abandoning the Agreed Framework, charging that its terms were too lenient to North Korea.

Bush Administration charges in October 2002 that North Korea had developed a secret second uranium enrichment program triggered a cascading breakdown of Agreed Framework. ${ }^{14}$ In early 2003 North Korea restarted the Yongbyon reactor and began reprocessing the plutonium stored at the Yongbyon site. North Korea is now believed to have reprocessed most of the 8,000 fuel rods, yielding between 20 and $28 \mathrm{~kg}$ of weapons-usable plutonium. In April 2005 North Korea again

\footnotetext{
${ }^{13}$ On this linkage see Joseph Cirincione and Joshua Williams, "Putting PSI into Perspective," May 3, 2005, //www. carnegieendowment.org/npp/publications/ index. cfm? fa=view\&id $=16827>$.

${ }^{14}$ For a good brief overview of key events, see Jonathan D. Pollack, "The United States, North Korea, and the Fnd of the Agreed Framework," Naval War College Review 56:3 (Summer 2003), esp. pp. 35-9.
} 
shut down the Yongbyon reactor to collect a new supply of spent fuel which could have been reprocessed by mid-2006, providing up to 15 kilograms more of weapons-usable plutonium. Taken together, this current stock of separated plutonium is enough for about 4 to 13 nuclear explosive devices ${ }^{15}$.

The collapse of the Agreed Framework in 2002 created a critical watershed. Many analyses, whether supporting greater confrontation or greater engagement, fail to recognize that unleashing North Korea's plutonium-based nuclear program has shifted the status quo fundamentally. Achieving a non-nuclear Korean peninsula now requires rolling back an existing capacity, making a "new deal" harder to reach. Many prior strategies to curtail North Korea's nuclear weapons development are not up to this qualitatively greater challenge.

This reality has become increasingly apparent - as has the inability of the Bush administration's ideologically-inspired confrontational approach to cope with it. This recognition gradually enhanced the ability of more moderate elements of the administration to steer policy toward less bellicosity and more engagement. After the November 2004 presidential election particularly, the administration became more willing to give North Korea assurances for its sovereignty and security and to work closely with China and South Korea to fashion plans to address the range of North Korea's wider problems.

However, internal struggling over how to handle North Korea has plagued the administration from its outset, exacerbated by the ongoing demands of the Iraq War (both mentally and materially). Harder-line factions have not relaxed their suppositions, and so the administration's engagement has been more grudging and tactical than fulsome and principled, less a foresighted handling of the crisis than a default to a policy of "ostrich engagement" - the continuation of "hostile neglect" with a more benign face. ${ }^{16}$ This inclination has overshadowed the Bush

${ }^{15}$ David Albright and Paul Brannan, "The North Korean Plutonium Stock Mid2006," Institute for Science and International Security (ISIS) , June 26, 2006 <http:// www.isisonline. org/publications/dprk/dprkplutonium.pdf>; Robert S. Norris and Hans M. Kristensen, "North Korea's nuclear program, 2005," Bulletin of the Atomic Scientists 61:3, May/June 2005 <http://www. thebulletin.org/article_nn.php?art_ofn=mj05norris > This estimate for the number of weapons North Korea could generate from its presumed plutonium stocks assumes North Korea 1) has only low technological capability, equivalent to the US at the creation of its first plutonium devices, and 2) is developing a relatively larger number of lower-yield weapons.

${ }^{16}$ See Wade L. Huntley, see "Ostrich Engagement: The Bush Administration and the North Korea Nuclear Crisis," The Nonproliferation Review 11:2 (Summer 2004). 
Administration's behavior throughout the Six-Party Talks negotiating process.

Nevertheless, the greater influence of more moderate Bush Administration officials in the second term enhanced US engagement of North Korea and helped propel the negotiating process. That process reached an apex with the joint statement of principles of September 19, 2005, articulating consensus on a set of principles addressing both goals and means. ${ }^{17} 16$ North Korea cormitted itself to end efforts to produce nuclear weapons, give up its "existing nuclear weapons," rejoin "at an early date" the NPT, and resubmit to IAEA safeguards, including readmission of intemational inspectors to its nuclear facilities. The agreement seemed to validate the negotiated approach to the current Korean nuclear crisis which both North Korea and the United States have, at various times, resisted.

From a longer-term perspective, a key provision of the agreement was its anticipation of a broader political settlement. Both the United States and North Korea agreed, "to respect each other's sovereignty, exist peacefully together and take steps to normalize their relations subject to their respective bilateral policies." This provision echoes similar intentions in the 1994 Agreed Framework - lack of progress on which may have been more disappointing in Pyongyang than delays on the material side of the deal. The September 2005 agreement also promises "the directly related parties will negotiate a permanent peace regime on the Korean Peninsula at an appropriate separate forum." The Korean Peninsula remains technically in a suspended state of war defined by the terms of the armistice that ended the Korean War in 1953. The agreement thus directly linked resolution of the muclear crisis to the creation of an overarching regional security accormodation, which could serve as an initial stage in development of a Northeast Asian cooperative security community.

But the agreement on principles did little to resolve trenchant practical differences. Some of those obstacles reemerged immediately, as widely divergent US and North Korean national statements exposed continuing deep divisions on several issues (particularly conceming North Korean retention of civilian nuclear facilities). Within the Bush

${ }^{17}$ United States Department of State, "Joint Statement of the Fourth Round of the Six-Party Talks Beijing, September 19, 2005" <http://www.state.gov/r/pa/prs/ps/2005/ $53490 . h t m>$. 
Administration, this divisiveness enabled hard-liners to push for new pressure tactics (including the financial sanctions that have become a central issue of late), further dampening momentum from the agreement. In this stalemated climate, North Korea on July 5, 2006, undertook a series of missile tests triggering widespread alarm and a UN Security Council condemnation; and then on October 9, 2006, test exploded a nuclear device, bringing the situation to a new nadir and eliciting the strongest UN Security Council action against North Korea in half a century.

North Korea's nuclear test marked an escalation of the crisis over its nuclear ambitions, but not a transformation. Since the breakdown of the Agreed Framework at the end of 2002, all of the implications of a nuclear North Korea have been at hand. This explains why international reaction to the test was more muted than many expected.

The US reaction to the test, relatively predictable and probably prepared in advance, continued to emphasize the need for a diplomatic solution while also pushing for new tighter sanctions and for creation of an "inspections cordon" to try to seal North Korean exports of nuclear materials and other military resources. China's reaction, while less predictable, was similarly balanced. China shares the goal of a nonnuclear North Korea, for many reasons, and termed the test "brazen" a term usually reserved for adversaries. ${ }^{18}$ But China has interests in Korea are broader than nuclear issue and distinct from those of the United States. Thus, China allowed UN Security Council Resolution 1718, passed six days after the nuclear test, to invoke Chapter VII of the UN Charter, denoting North Korea's actions as a threat to global peace; but China insisted the resolution refer to Chapter VII's Article 41, not Article 42, thereby specifically ruling out the use of armed force. ${ }^{19}$ Immediately following the passage of the resolution, China's UN Ambassador Wang Guangya issued an extraordinary statement seemingly rebuking the inspections cordon China had just voted to implement:

China does not approve of the practice of inspecting cargo to and from the DPRK. We therefore have reservations about

\footnotetext{
18 "North Korea's Nuclear Test: The Fallout," Intemational Crisis Group Asia Briefing No 56 , November 13, 2006, p.9

${ }^{19}$ United Nations Security Council, Resolution 1718, October 14, 2006 http:// daccessdds. un.org/doc/UNDOC/GEN/N06/572/07/PDF/N0657207.pdf
} 
the relevant provisions of the resolution. China strongly urges the countries concerned to adopt prudent and responsible attitude in this regard and refrain from taking any provocative steps that may intensify the tension. ${ }^{20}$

Thus, UN Security Council consensus veiled the ongoing divergence of US and Chinese approaches to the issue, which constitutes a continuing obstacle to developing the kind of cooperative regional security environment that would enable the Six Party Talks process to progress more dramatically.

Nevertheless, the recognition by all parties that North Korea's October 2006 nuclear test had not dramatically altered the situation enabled the tactical consensus around a measured reaction to the test that in turn supported the otherwise surprising early resumption of progress in the Six-Party Talks. That progress produced the implementing agreement of February 13, 2007, restoring momentum toward the negotiated solution to Korean Peninsula nuclear conflicts outlined in the September 2005 "Statement of Principles."

The terms of the new agreement would shut down to research reactor at the Yongbyon site that produces the plutonium North Korea uses for its weapons program. In exchange, North Korea would receive immediate shipments of fuel oil to prop up its energy-strapped economy. Eventually North Korea would verifiably dismantle all nuclear weapons capabilities, receiving further energy aid, release from economic sanctions and normalization of political relations.

The deal does not replace the 1994 Agreed Framework, which mapped a never completed course to complete denuclearization of North Korea. Indeed, the new deal leaves recent develops - such as North Korea's withdrawal from the NPT and disposition of its existing plutonium stocks - to future negotiations. In this and other practical senses, the new agreement is considerably less precise than the Agreed Framework.

In terms of offering a basis for building broader regional security capacity, the new deal is also more tenuous than its predecessor. Bush Administration principals observe that, whereas the Agreed Framework

20 "Explanatory Remarks by Ambassador Wang Guangya at the Security Council After Taking Vote On Draft Resolution on DPRK Nuclear Test," Permanent Mission of the People's Republic of China to the UN, October 14, 2006 <http://www. china-un.org/ eng/smhwj/2006/t276121.htm>. 
was mainly a bilateral accord, the new deal involves commitments by North Korea's key regional neighbors included in the Six Party Talks China, Japan, South Korea and Russia. But this is not the whole story. Implementation of the Agreed Framework energy provisions was vested in the Korean Energy Development Organization (KEDO), which enlisted the active support of South Korea and Japan; its Executive Board also included the European Union, and nine other countries joined as members.

At the diplomatic level, the Six Party Talks is a more genuinely multilateral process, but this too is deceptive. The Bush Administration was to a certain extent hiding behind this multilateralism to avoid direct negotiations with North Korea - despite support for such direct dealings by the other four parties. Eventually the United States bent to this necessity, meeting directly with North Korea in Berlin in Jamuary 2007, separate from the Six Party Talks process in Beijing, in a key encounter that set the stage for the new deal.

Thus, the new deal provides only a small step forward in fulfilling the promise of broader regional security cooperation offered by the September 2005 Statement of Principles. Political commitments, as well as formal commitments, have yet to be restored even to the minimal levels sustained under the Agreed Framework. Keeping progress toward a broader political settlement on track is as important as seeing more imediate practical agreements implemented forthrightly.

\section{The Regional Security Imperative}

The nuclear test has proven that achieving a non-nuclear Korean peninsula now requires rolling back an existing capacity. Although North Korea still has very far to go before it is a full-fledged nuclear power, no country has ever given up a publicly demonstrated nuclear weapons capability. The only two cases of nuclear rollback - South Africa and the former Soviet republics - involved governments that had not embraced nuclear weapons in their security policies. And, both those rollbacks were triggered by dramatic regime change - an ominous precedent for advocates of a peaceful negotiated resolution to North Korea's nuclear ambitions.

Today, it is clearer than ever that the only route to a peaceful denuclearization of the Korean peninsula lies down the road of engagement and negotiation. Misbegotten dalliances with cowboy 
confrontation have simply made that road longer and rougher. The international community must now not only pursue rolling back North Korea's nuclear weapons acquisition but also take measures to prevent a nuclear North Korea from fuelling regional security conflict and global nuclear proliferation. Both these goals point to the need for security cooperation among the key interested parties, particularly the United States and China, which encompasses the full context of North Korea's future regional role, not merely the nuclear crisis alone.

The difficulty of these challenges underscores the importance of the September 2005 agreement's anticipation of reaching a wider regional accord.

US pledges to normalize relations and provide negative security assurances should carry great weight for a country subjected to cavalier talk of "regime change" since the advent of the Bush Administration language likely reinforced in North Korea's eyes by the US invasion of Iraq and by inclusion of North Korea as a potential target for nuclear counter proliferation strikes in US planning. Much would need to be worked out over the nature and limits of US negative security guarantees. Nevertheless, the costs of early and significant US moves toward normalizing relations are relatively cheap compared to the potential benefits that could accrue in smoothing negotiations over more contentious tangible matters.

In this context, the promise offered by the six parties' mutual commitment to negotiate a permanent peace regime on the Korean Peninsula is particularly significant. A peace treaty to end the formal state of war would promote a wider East Asian cooperative security regime to supplant the deterrence and balance of power dynamics now dominating regional relations.

But this linkage is symetric: efforts by East Asia's principal states to forge such broader cooperative mechanisms would reinforce the SixParty Talks process and bolster prospects ultimately to resolve Koreaspecific conflicts. In the new post-Agreed Framework circumstances, easing the current Korean deadlock now also depends on progress toward broader regional cooperation. More than ever, building enduring regionwide cooperative security mechanisms is a prerequisite, not merely a hoped for consequence, of peaceful achievement of a non-nuclear Korean peninsula. 
Many analysts have long called for a "bold initiative" for dealing with North Korea, and most reasoned proposals call for some combination of "carrots" and "sticks." But with the new status quo now enabling North Korea to grow its nuclear arsenal to the limits of its technological capabilities, anticipating broader regional security cooperation as an outgrowth of the Six-Party Talks process is no longer sufficient. Reversing the trajectory taking North Korea toward becoming a full-fledged nuclear-armed state requires a "bold initiative" reaching beyond Korea itself, setting as a forefront goal creation of a sturdy East Asian security community.

The Bush Administration is capable of such thinking: Secretary of Defense Donald Rumsfeld once embraced the principle, articulated earlier by US President Dwight D. Eisenhower, that "if a problem cannot be solved, enlarge it." James Goodby has applied this adage to the Korean confrontation:

The nuclear issue can only be resolved within a framework that is as large as the strategic issue of which it is a part. ... In parallel with [the six-party] talks, or independently if the talks are not resumed, [the parties] should work out a mandate for a permanent mechanism to promote security and cooperation in Northeast Asia. ... The mandate for a security community should be as broad as that of the Organization for Security and Cooperation in Europe. ${ }^{21}$

But so long as Bush Administration policy-makers sustain their ideational preference for emancipatory militancy over multilateralism, lasting mechanisms of regional security cooperation will be elusive. Yet a minimalist begimning, oriented around a more realist, problem-solving approach, is feasible, and the initial parameters of such security cooperation are straightforward. Regarding Korea conundrums, the United States and China could find common ground on both the impracticality of "regime change" and the importance of an active role for the UN Security Council, forging the Sino-American concord needed for a lasting solution. But reaching that convergence would require the United States and China to build a more collaborative strategic relationship regarding Northeast Asia more broadly and to involve the

${ }^{21}$ James Goodby, "Enlarge the North Korean problem," International Herald Tribune, Tuesday, June 21, 2005. C.f. Huntley, "Ostrich Engagement." 
region's other principal parties - constituting a "small m" multilateralism along the lines of the early nineteenth century European "Concert of Powers." 22

Accordingly, the aspiration to negotiate a permanent peace regime on the Korean Peninsula should move to the forefront of attention and aim also to establish broader security cooperation on the basis of practical region-wide problem solving (rather than more ambitious institutionbuilding) . Unlike with the hard details of the muclear confrontation, nongovernmental civil society initiatives can play a vital role in nurturing the innovative ideas and supportive climate necessary to such broader political progress. Ongoing advocacy of Northeast Asian nuclear weapons free zone proposals, for example, can (and should) be oriented to contribute to this broader political goal as well as to refine and implement the concept itself.

\section{Conclusion}

The Korean nuclear crisis has of late been a roller coaster ride - the ascent to the September 2005 statement of principles, the plunge to the October 2006 nuclear test, the climb back to the February 2007 implementation deal, and now the suspension in mid-air awaiting North Korea's shut down of the Yongbyong reactor. Stabilizing this volatility requires addressing the wider context of the crisis. Despite the trenchant material obstacles to resolving the Korean nuclear confrontation, the greatest challenges are political and symbolic.

This is a major reason why future prospects are overshadowed by the ideational predispositions the Bush Administration brings to its engagement of this problem (not to mention the ideational blinkers of Kim Jong-il's regime $\left.{ }^{23}\right)$. The United States has the most latitude for enterprise. But neither the passion of the Bush Administration's emancipatory militancy nor the ostensible sobriety of the administration's

${ }^{22}$ Paul Evans, "Constructing Multilateralism in an Anti-Region: From Six Party Talks to a Regional Security Framework in Northeast Asia?," conference on Cross Currents: Regionalism and Nationalism in Northeast Asia, Shorenstein Asia Pacific Research Centre, Stanford University, May 11-12, 2006; revised July 8, 2006; see also David Capie and Paul Evans, The Asia-Pacific Security Lexicon (Singapore: Institute of Southeast Asian Studies, 2002), pp. 77-81

${ }^{23}$ While this essay does not explore the ideational determinants of the policies and strategies of Pyongyang's government, it may be assumed these determinants are in ways equivalent to those prevailing in the Bush Administration. 
critics is a sufficient basis for the initiative, innovation and imagination - in a word, idealism - that building an East Asian security commuity requires.

The end of the Cold War did not just terminate the superpower nuclear arms race; it also marked a major step toward closing the great ideological battles that have defined much of modemity. But an emerging global consensus on the values of a rule of law, political and economic opportunity, democracy and human security is not an "end of history." The defining task of the twenty-first century is to refine and articulate this consensus in ways that reinforce rather than repress social, cultural and religious variance, and to institutionalize this consensus through improved global governance offering effective mechanisms for peaceful conflict resolution. Northeast Asia today is a focal point of this global challenge.

In justifying its stark confrontations with autocratic regimes and its ambitions for democratization globally, Bush Administration supporters often allude to the "democratic peace" - the finding that democratic countries tend not to fight wars with each other. But such interpretations of the implications of this phenomenon are at best partial. Many in Asia, particularly in South Korea, have concluded that the United States is avid in promoting democratic development in other countries but loathe to accommodate divergences from US desires that may emerge when that democratization is realized. ${ }^{24}$ Such accommodation is a necessary concomitant of the "democratic peace" ; the Kantian conception of a federation of republican governments premises genuine cooperation among these governments, not rote allegiance to the strongest of them. ${ }^{25}$ This conception further appreciates that sturdy enlightened government rises from a foundation of genuine self-determination, not from the merely formal exercise of democratic instruments under the shadow of foreign military occupation.

The Bush Administration is right to see a link between North Korea's nuclear ambitions and the broader political evolution of the region. But this linkage does not necessitate - or justify - making "regime change" the principal policy objective. US security policy ought to be based on a

\footnotetext{
${ }^{24}$ Workshop Report, "America in Question: Korean Democracy and the Challenge of Non-Proliferation on the Peninsula," Seoul, ROK, 10-11 May 2005

${ }^{25}$ For an expansion on this point, see Wade L. Huntley, "Kant's Third Image: Systemic Sources of the Liberal Peace," Intemational Studies Quarterly 40:1 (March 1996) .
} 
vision for a better world. But the world deserves a voice in constituting that vision. Improved govemance within states is rarely achieved through means that widen the divides between states. Neither a peaceful nonnuclear solution on the Korean peninsula nor the full embrace of North Korea within the global community of nations are achievable through confrontation. These goals require engaging the Pyongyang regime as a sovereign equal, while also grappling with the complex tensions involved in East Asia's own encounter with today's globalizing world.

Building principled law-based global govemance of this nature is now more than ever a prerequisite to strengthening global nomproliferation efforts. States in the world, and factions within states, increasingly rely on nuclear threat-making for security and embrace nuclear capabilities as symbols of power and stature. Refashioning the conditions of global governance to break this insidious linkage between nuclear armaments and daily politics is essential. IAFA Director General Mohamed El Baradei makes a similar point:

Clearly, the development of a security system that does not depend on nuclear deterrence or nuclear weapons will be a prerequisite to a roadmap for effective disarmament. Until the intemational commuity fully engages on the development of such a system, achieving complete nuclear disarmament will remain in the realm of rhetoric. ${ }^{26}$

Despite its rejection of these premises, the Bush Administration's generic recognition of the political dimension of nuclear proliferation is overdue. In a more consensually developed form, this perspective can function as an essential adjunct to the Cold War era's narrower focus on limiting material nuclear capabilities and upholding technical nondiscrimination. Such a broadening of perspective is vital in responding to today's nuclear challenges, in which abstract strategy matters less and the broader threat-making and symbolic values of nuclear weapons possession matter more. The ideal of eventual nuclear disarmament requires reversing this political and symbolic linkage, which in tum requires elevating conditions of global govemance -at both national and intemational levels - above the mean dictates of anarchy.

${ }^{26}$ Mohamed ElBaradei, "Nuclear Non-Proliferation: Global Security in a Rapidly Changing World," Statement to the Camegie Intemational Non-Proliferation Conference, Washington, DC, June 21, 2004 (http://www.iaea.org/NewsCenter/Statements/2004/ ebsp2004n004.html). 
The prerequisite is both material and normative: good governance means good institutions, but the necessity of consensual acceptance means good institutions cannot be imposed by fiat. Hence, the governance goals, which are now a prerequisite to nuclear disarmament, can only be achieved through multilateral cooperative processes building on historic foundations of intemational law and transnational community. Ad hoc self-serving unilateralism is antithetic to such outcomes. 